\section{水稻开花前后光合作用 产物的韧变与分配}

本試驗采 1957 年进行的, 目的是分析水稻在开 花前后光合作用产物的类型及在植株各器目中分贷的 情况。以秀载“老来素”品种为材料, 在抽穗时及拜熱 期各做試驗一次, 处理时整株用玻璃缸啅起, 通入放 射性 ${ }^{14} \mathrm{CO}_{2}$, 在阳光下进行光合作用坐小时, 收回未 作用的 ${ }^{14} \mathrm{CO}_{2}$ 。植株靜置一天，然后将吓、䩗、莖、 穗、根切开，分別固定。各样品㚬分为 (1) 热酒精 $(80 \%)$ 提出物，(2)稀酸 $(2 \% \mathrm{HCl})$ 水解物，及(3) 浓 酸 $\left(80 \% \mathrm{H}_{2} \mathrm{SO}_{4}\right)$ 水解物，各取一部分計数，算出总眿 冲数，及各器官中各类型物稹所含放射性的百分比。 結果見附表。

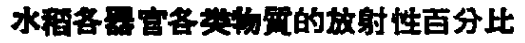

\begin{tabular}{|c|c|c|c|c|c|c|c|c|}
\hline & \multicolumn{4}{|c|}{ 抽 䅹 期 } & \multicolumn{4}{|c|}{ 乳 敬 期 } \\
\hline & $\begin{array}{l}\text { 酒精 } \\
\text { 提取 }\end{array}$ & $\begin{array}{l}\text { 程酸 } \\
\text { 水解 }\end{array}$ & $\begin{array}{l}\text { 哝酸 } \\
\text { 水解 }\end{array}$ & 总計 & $\begin{array}{l}\text { 酒精 } \\
\text { 提取 }\end{array}$ & $\begin{array}{l}\text { 稀酸 } \\
\text { 水解 }\end{array}$ & $\begin{array}{l}\text { 浓酸 } \\
\text { 水解 }\end{array}$ & 总部 \\
\hline 叶 & 55.6 & 6.0 & 0.8 & 62.4 & 61.4 & 8.1 & 0 & 69.5 \\
\hline 筩 & 13.3 & 2.8 & 0.4 & 16.5 & 9.3 & 1.9 & 0 & 11.2 \\
\hline 茎 & 9.9 & 2.3 & 0.9 & 13.1 & 2.2 & 0.6 & 0 & 2.8 \\
\hline 穗 & 4.5 & 1.0 & 1.6 & 7.1 & 7.2 & 9.9 & 0 & 17.1 \\
\hline 根 & 0.9 & 0.4 & 0 & 1.3 & 0.3 & 0 & 0 & 0.3 \\
\hline 总偖 & 84.2 & 12.5 & 3.7 & 100.4 & 80.4 & 20.5 & 0 & 100.9 \\
\hline
\end{tabular}

由表中可見:

（一）叶中放射性最高，表示經过一天以后，大部 分同化物仍留在叶中。这一点与 1958 年的結果 ${ }^{[1]}$ 有 些不同。那时以 ${ }^{14} \mathrm{CO}_{2}$ 供給旗叶，三天后分析，則絕 大部分放射性聚集在穗中。其原因是一則时間长（三 天)，运轉較多，二則是旗叶的光合产物主要供給穗， 本試驗則运轉只有一天时間, 而且各叶㚬得到 ${ }^{14} \mathrm{CO}_{2}$, 下面各叶与旗叶不同，可能存留的落多，大麦、小麦 均如此 ${ }^{[2,3,4]}$ 。

（二）抽穗期䔲中放射性較高，乳熟期很低，穗中 即正相反，乳熟期累积最速，指出开花后同化物盾主 要向穗中轉移，与以前結果相符 ${ }^{[1-6]}$ 。

（三）根采的放射性极小，指出同化物不入根部， 特別是乳熟期，根系已完全停止生长。

(四)无論在抽穗或釈熟期，絕大部分放射性 (80 $-85 \%$ ）均在酒精可溶的部分中，这一部分主要包括
糖、氨基酸、有机酸等的光合作用直接产物，表示 一天之內轉化不多。叶中含最最大，表示流动亦不 快 ${ }^{[1,2]}$ 。

（五)稀酸水解物质(淀粉、牛秄維素、蛋白盾等), 在乳熟期比在抽穗期多，特別是在穗里，比例賭加十

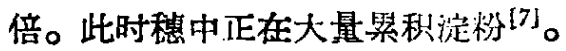

(六)浓酸水解物盾包括紬維素等，伍抽穗期台梢 有形成, 穗中較多。但在乳熟期間不論在何器官中, 这类高分子的結构物质均完全不再形成 ${ }^{[2]}$ 。

进一步的研究正在进行的。

\section{沈允鋼 殿宏章 沈巩森}

(中国科学院掼物生理硼究所)

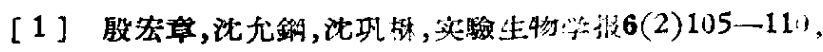
1958.

[2] Archbold, H. K., Nature 156 (3951) 70-73, 1945

[3] Кравцова, Б. Е. Пок. Акал. Наук СССР 113. (5) $11631164,1957$.

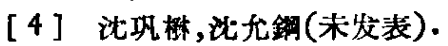

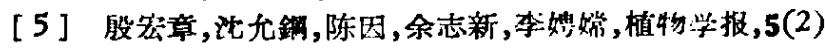
$177-194,1956$.

[6] Беликов, И. Ф., Фязиол. Раст., 2, 354-357, 1955.

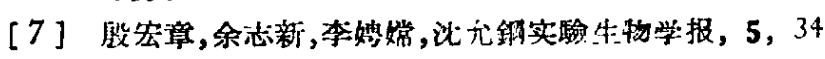
$-44,1956$.

\section{地台活化說及其找矿兲义}

地台区是一个“稳定”区，是由風于“活动区的地槽 区“偠化”轉变而成的。长时期以来，在旧的地质学覌 念中，人們都馀为它是地壳发展的最后形式。可是， 由于苏联学者在近年所作的发現，我們已經訩識到， 有些地台区扭不是生成以后就不再变化，而是会經重 新活动过。根据作者的研究, 这种現像在中国是特別 鼠著，护見于世界上其他許多地方，它实系一种相当 普㴜、相当突出的現像。

凡地台区当其建立完成，經过或长或短的“稳㹥” 阶段以后，又重新获得了高度的活动性，出現了留然 超越地台型地党运动范疇的活动，抹再度博化成为新 活动区的現倸，作者統称它做“地台活化”。这种現像 的进行过程，可分为四个阶段：（1）初动朝。其特征 为在古地台里面, 开始出現拱曲运动或断㣞运恸久或 二者策有，形成了升降幅度很大晸且进行也较速的隆 起和凹地，分別称为“地穹”和“地洼”，柏關排列，散 俅各处。随差地穹的被侵蝕, 地洼中出現就初的“地

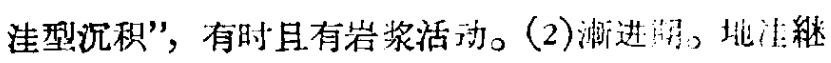


䍃下陷, 沉积継續加厚, 时有較强的构造运动和岩浆 活动。（3）极烈期。此时地洼的下降幅度更加增大, 沉积継續增厚。同时有剧烈的构造运动, 包括褶觟、 断裂、逆掩等, 扭有大量岩浆侵入, 部分地区有强烈 的火山噴发, 所有在此以前生成的地洼沇利及原地台 区的沉积盖层以至譛貱基底, 同受它們影响, 抹构成 表現为“准綫状山脉”的“地洼䙫貱带”。(4)余动期。 在“地洼褶频带山間凹地”中，产生了“余动期地洼沉 积”, 一般地說, 活动已轉趋微弱, 但在主要余动期阶 段，仍可有較强的沟造变动及岩浆作用。

以現知者而諭, 地台活化遍見于除份未詳知的澳 洲及南极洲以外的各个大陸，尤以亚洲所見者为最广 泛。諭其发生时代, 从上古生代开始显漖, 日頓泹荻 期; 至中生代迅速开展，日华夏期；新生代仍継續 进行，日“中亚期”。

伎其主要特征上的差別, 地台活化可以別为四大 类型，郎 (1)頓湜茨型，以形成大型地洼，其中沉积 特別巨愿为特色; (2)华夏型, 其主要特色为形成成 列散分的小型地洼, 岩浆活动强烈; (3)东非型, 产 生大規模的断裂，火山噴发剧烈；（4）中亚型，主姴 特征为发生大幅度的拱曲及上升财伐有断裂。

地台活化的性稹，是代表地冢运动的一种 新类 型, 它代表地壳发展的新方向。这种現像, 鼠然与地 台型的地党运动有本稹上的区別, 故发生过这种現像 的地台区，已不能再頑作属于 “稳定” 区范譆的地台 区。另一方面, 这种現像虽和地槽型运动有若干地方 可相比抧，但实际上汼不相同，所以，由此形成的新 活动区，也不能簡单地看作地槽区。显然，它是地壳 中秤在地槽区及地台区之后出現的 “第三基本构造单 元”。

由地台活化所形成的代表地壳第三基本构造单元 的新活动区，以在其中形成地洼及产生地洼型沉积为 䨘要标志，因此叫做“地注区”。又因它是地台活化的 产物,故切可称“活化区”。地洼区的主酡特征，是在結 构上具有三个主要构造层，它們自下而上依次地分別 由属于地槽型、地台型及地洼型沉积的基本层翌所构 成。其中第一、二构造层显然系継承了該处古地台区 所遗留下来的柏旇基层及沉积盖层，而“第三构造层” 則系新成的和特有的。因为它是由地洼型沉积构成 的, 故名“地洼沉积层”(其同义語为“活化构造层”)。 这个新构造层的发現，使我们看出地洼区无論对于地 台区抑地槽区，都显出更复杂的发展过程和本稹上的 差別，表現为在組䋨形式上比它們中任何一个都較复 杂、較高級。在地层方面，組成第三构造层的地洼型
沉积, 且有在古地台上形成胹不与任何地槽发展相联 系的毛拉石建造, 有时夹有多量火山岩, 扭以陸相沉积 为主。在构造上, 主型特征为具有以宽展型为主、偶也 可有紧閉型或近于紧閍型的榴毁, 扭有逆掩及断致。 岩浆活动方面, 其特点为規模巨大而强烈, 富于酸性 侵入岩和地洼型沉积伴生或同时，其活动总趋向大多 数大体上自酸性发展到基性 (即前期以酸性及中性岩 占优势，后期以基性岩較普滆)。新构造运动一般胎 烈, 除升隆、单斜、断裂、拕曲外, 有时还有拱曲及 潜解。地貌上一般地以起伏显著, 具有大多数属于滩 綫状山脉的中山至高山为特色。

在中国境內，地洼区主要分的于东部，師“中国 东部地洼区”。它是由中国古地台于古生代后期开始 于中生代时大面积活化解体轉化而成的，属于华贾 型, 它継承了中国古地台几个古台块的某些特点, 可 以划分为三个部分，即东北地洼区，华北地洼区及华 南地洼区。它們的中部还有一些地区其活 化程卧較 低, 可以基本上看作残留地台区（实际上已略受活 化), 被它們包围着。这些地洼区中有一部分岩浆活 动特別强烈, 除大量花岗岩侵入体外, 还有剧烈的火 山噴发，特称“閩浙式的地洼区”，見于它們的东緗以 及互相分界处。岩浆活动較弱的地带, 則称“湖北式 地洼区”，主要見于它們的西部。

地台活化其有重大的成矿作用, 这就是地台活化 型成矿作用，也可叫“地洼型成矿作用”，包括地洼型 沉积成矿作用和“地湱型岩浆活动成矿作用”。由此所 带来的矿产，十分丰富。“地洼型沉积矿床”有煤、油 頁岩、鉄、鋁、鎮、盐类等, 主要特征为矿层厚集及 矿石成分稳定性小，薄层較常見，但层数往待較多， 有些可有巨大的儲量。“地洼型煤田”及“地洼型油頁 岩矿佅”師其代表。“地洼型內生矿床”，以和酸性至 中性侵入岩有关的有色金属和稀有及分散金属等为最 重要，有时大量存在; 此外也有鉄矿（例如大治式）。

地洼区所蓝藏的矿产, 由于它的地质发展交无論 比地慒区抑地台区都較复杂, 所以它的成矿作用发展 史也皎复杂。一方面它継承了它的前身毁地台区所遺 留一决的地槽型及地台型矿产, 可在第一、二构造层 中找到。另一方面它父增添了自己特有的地洼型沉积 矿佅和內生矿休：前者存在于地洼沉积层中，后者則 可見于各个构造层之受地洼型岩浆影响的部分, 它們 中有一部分和地槽矿区中党見的矿产相类似。因此地 洼区的矿产种类是十分多样而丰富的。既可找到地台 型矿朱，又可找到前此記为只見于地槽区的矿休。

地台活化說在理諭意义上阙明广（1）地孛发展抹 
非到了地台区阶段師停止不进, 継在由地槽区轉化为 地台区这一阶段之后，还有由地台区轉化而成的第三 基本构造单元。（2）活动区和“稳定”区的关系，是䛨 鉦地互相轉化的关系, 地壳的发展, 就是由于活动区 和“稳定”区矛盾两方的斗爭, 互相递迭, 螺旅升进; 作者所提出的反映地壳发展規律的“动定递进說”郎是 由它可伸发展而成的。

在实用的意义上，地台活化說的作用有四: 帮助我們正确邻識一个地区的大地构造性原，弄清区 內有过多少种成矿作用出現过，使我們有根据估計区 內可能有那些矿产存在, 以及存在何种岩石区域及什 么时代的地层里存在。2)使我們訩識前所未知的一种 成矿作用，一“地洼型成矿作用”（師地台活化型成 矿作用)攻由它带来的矿产，使我們在找梁某些矿种 或某些矿佅类型时有了新的方向。（3）給我們指出地 注区矿产的多样性及其所在，扩大了找矿范围。过去 訆为只能見于地槽区或地台区, 而不可能同在一个构 造区内发現的矿产种类或矿床类型，却可以同在一个 地洼区內找到。（4)使我們能正确决定找矿方向, 減 少由于普查勘探地区的大地构造性稹不明所可起的浪 费。

\section{陈国达}

（中南矿治学院地盾系 中国科学院湖南地稹研究所）

\section{小兴安岭、完达山和张广才岭 北端地質矿产概要}

黑龙江流域棕合考察队小兴安岭地稹队的考察工 作开始于1956年，考察地区包括东經127度以东、132 度以西、黑龙江以南、哈尔滨一生丹江一密山鉄路綫以 北地区。面积达九万平方公里。

我們經过两年多的工作，对这幅員广大的地稹空 白区获得了比較全面的了解，划分了各个时代的地层 和岩浆活动,初步闻明了䪭区地稹結构和地稹发展史, 对于各种矿产的分们规律也获得了初步結諭。

研究地区位于中朝地台的东北部分（东北台块和 张广才岭准褶解带)。区内最古老的元古代地层，主 要分向在小兴安岭东部兴东、依兰、樺川、勃利、麻 山和壮丹江一带。可分为上、下两部分:下元古界(黑 龙江系)分解于古老复背斜的軸部，主系各种片岩、片 麻岩和角閃岩，頂部有白云盾大理岩，可見厚度达 8000-9000公尺。从岩石的区域变盾程度、岩石組合 和构造情况来看, 黑龙江系相当于辽宁的鞍山系和山
西的五台系。上元古界 (䛲山系或兴东系) 主系黑云 母、柘榴石、矽綫石片麻岩和片岩、含石墨的大理 岩、含石墨的石英片岩和石英岩等，构成古老复向斜 的核心，最大卓度达 4000-5000 公厄，可与东北南 部的辽河柔以及华北的海沱系相对比。

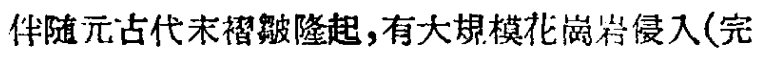

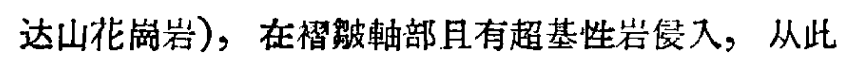
本区就成为中朝地台的一部分。

震且一寒武系在苏联小兴安岭和烏苏里江流域 有 广泛的发育，在我国仅見于小兴安岭东部靠近黑龙汇 部分(风翔)，为条带状灰岩，它相当于苏联震且一寒武 柔的下部。

中古生代时，台块东部受到中泥禡紀吉維琴世海 浸, 在黑台、宝清一带有所沉积，主系生汤碎居为 岩、砂岩、含粉砂盾矽盾頁岩，靠近中部有酸性凝灰 岩夹层，可見厚度在 2300 公尺以上。

上古生界見于张广才岭西坡阿什河流域，采答年 分分的海相灰岩和砂岩(玉泉菜)，可見度度在 300 公 尺以上。而广才岭东坡，大致由鹤萹西南的舆明至牡 丹江以西地区，活化剧烈，沉积过程中体有火山噴发 作用。在晨明附近, 岩层是由灰岩、砂岩、砂质頁岩 組成的晨明岩系，厚达 1100 介尺，鼠明村东南的宝 泉附近，佮发育有一套噴发沇积岩(宝泉岩䒺)，厚 1600 公尺，办暫定其为上古生界。在张广才岭东坡横 道河子、三道河子一带，系粉砂岩、泥岩、流紋岩 夹碳酸盐岩层，向上过渡为被植物化石所确定的石炭 二迭紀陸相岩层，厚度在4000公尺以上。上氹上古生 代活动区自晚期海徆化崖岩的侵入隆起而娜趋稳定。

中生界在本区內相当发育，其分们在一定程度上 受古老构造所控制。大致可分为三个溯續发有带: 北 带由兴东、鶴崗至双鴨山，呈照蹄形分优; 中带沿倭 肯河流域由西向东再折向东北，䉼續伸延至宝清; 南 带呈北东东向，自鸡西向生丹江方向延展。中生界火 致可分为三套岩层: 下部䒺粗粒砂岩、砾岩和煤层, 局部有粘上稹頁岩夹层, 中部系粗粒和細粓砂岩，粉 砂岩，粘土质頁岩和凝炎稹砂岩，含蝶层，局部有爍 岩,合称鳮酉梳。共上部不整合复盖着檴山統砾岩、粗 砂岩和頁岩等, 再徍上常发育有中酸性火山碎屃岩, 总㚖度 2000-5000 公尺。在小兴安岭东部、分水溯 岭西部以及张广才岭西坡，广泛发育有中酸性噴发岩 及其凝灰岩，同时在鉄力、玉泉、小岭等地有燕山期 花崗岩类侵入。

新生界: 第三系基本上沿着新生代断裂活动較强 的烃花江流域、螞蚁河流域和逊河流域分份，系砂 